\title{
Structural control on the initiation and development of the Biała Wiselka Landslide Complex (Silesian Beskid, Outer Carpathians, Southern Poland)
}

\author{
Rafał Sikora \\ Polish Geological Institute - National Research Institute; ul. Skrzatów 1, 31-560 Krakow, Poland; e-mail: rafal.sikora@pgi.gov.pl \\ (C) 2018 Authors. This is an open access publication, which can be used, distributed and reproduced in any medium according \\ to the Creative Commons CC-BY 4.0 License requiring that the original work has been properly cited.
}

Received: 25 January 2018; accepted: 3 March 2018

\begin{abstract}
The numerous landslides which have developed in the mostly Cretaceous to Eocene turbiditic rocks of the Silesian Beskid are genetically and geometrically controlled by bedrock structural features, the Biała Wisełka Landslide Complex being no exception. Its location is in the headwater area of the Wisła River, on the slopes of Mt. Barania Góra (1220 m a.s.l.). The bedrock is represented by flysch strata of the Silesian Nappe (Outer Carpathian Fold-and-Thrust Belt), or, more specifically, the Upper Cretaceous turbiditic Upper Godula and Lower Istebna Beds of the Godula Thrust Sheet. The research work consisted in their mapping and structural analysis, facilitated by the use of a high-resolution digital elevation model based on LiDAR data. A comparative analysis enabled the determination of the relationships between landslides and the bedrock structure. The study results point to significant roles being played by the joint network, fault systems, the structural arrangement and the lithology of rock strata in the initiation and evolution of the studied landslide complex. An additional result of the methods applied methods was the identification and characterization of previously unknown fault zones in the study area.
\end{abstract}

Keywords: landslides, structural geology, lineaments analysis, LiDAR, Silesian Nappe, flysch Carpathians

\section{INTRODUCTION}

Globally, landslides cause significant losses and pose considerable danger to properties, infrastructure and life in many regions (Cała 2009, Wójcik \& Wojciechowski 2016). For these reasons they are subject to interdisciplinary research including especially geological, geomorphological and geoengineering. The research is carried out on different aspects of the landslides, among others: mapping, formation conditions, statistical risk analysis, monitoring of the dynamics, as well as stabilization and prevention. The results of the research are highly practical. Management of landslide-prone areas requires an understanding of the causes and processes that lead to landslide formation.
The formation factors are differentiated as active and passive (Bober 1984, Thiel 1989, Zabuski et al. 1999). Passive factors are the morphological features of the slope (e.g. length and inclination) and the geological structure and characteristics (e.g. lithology, dip and strike of the beds, tectonic structures). A particular aspect of the research on geological factors of landslide formation is their lithology, as well as the tectonic characteristics of the bedrock. The study of these specific features provides very interesting and scientifically meaningful information that allows us to understand better landslides in mountainous regions.

Attempts to link landslide formation with the lithostratigraphic and tectonic characteristics of the bedrock in various regions of the Outer 
Carpathians are present in the literature (Bober \& Oszczypko 1975, Mastella 1975, Bober \& Wójcik 1977, Nemčok 1982, Bober 1984, 1990, Wójcik \& Zimnal 1996, Wójcik 1997, Margielewski 1998b, 2001a, 2002, 2006, Margielewski \& Urban 2003). Some of these studies focused on the Silesian Beskids area (Ziętara 1964, 1968, 1988, Ziętara \& Bajgier 1989, Bajgier-Kowalska 1996, Margielewski \& Urban 2000, Margielewski 2004, Margielewski et al. 2007, 2008, Panek et al. 2010, 2011, Sikora \& Piotrowski 2013d).

The specific characteristics of the bedrock in the Silesian Beskids area, where over 950 landslides have been recorded (source: Landslides Counteracting System - SOPO database), has a strong impact on their geometry and size. The numerous landslides in this area attain significant dimensions and, when closely adjacent to one another, constitute so called landslide complexes. Moreover these landslides were often reactivated and its surface morphology is a results of multistage slope deformation. The paper presents the results of research aimed at finding the relationship between the formations of the bedrock structure within the area of Mt. Barania Góra (1220 m a.s.l.) in the Silesian Beskid. The spatial and geometrical relationships between morphological features (escarpments, tension rifts) and joints and faults present within the rock mass, as well as variations in lithology, have been thoroughly documented within the Biała Wisełka Landslide Complex (BWLC). It is one of the largest and most interesting landslide complexes in the Western Carpathians, and provides an exemplary area for this type of study and the testing of the methodology. The results presented in this paper are a development of those put forward earlier by the author and discussed at several conferences (Sikora 2014a, 2014b, 2015, 2017).

\section{GEOLOGICAL AND STRUCTURAL SETTING}

The studied landslide complex is located in the Mt. Barania Góra range, belonging to Silesian Beskid in the Outer Western Carpathians (OWC) (Starkel 1972). The research was carried out on Wisła river headwater area (in the valleys of Czarna Wisełka, Biała Wisełka, Malinka and Gościejów streams) that spreads over the western slopes of the Mt. Barania Góra (1220 m a.s.l.) range. Several promontories expand from the range towards the west in a fork-shaped pattern of valleys and crests.

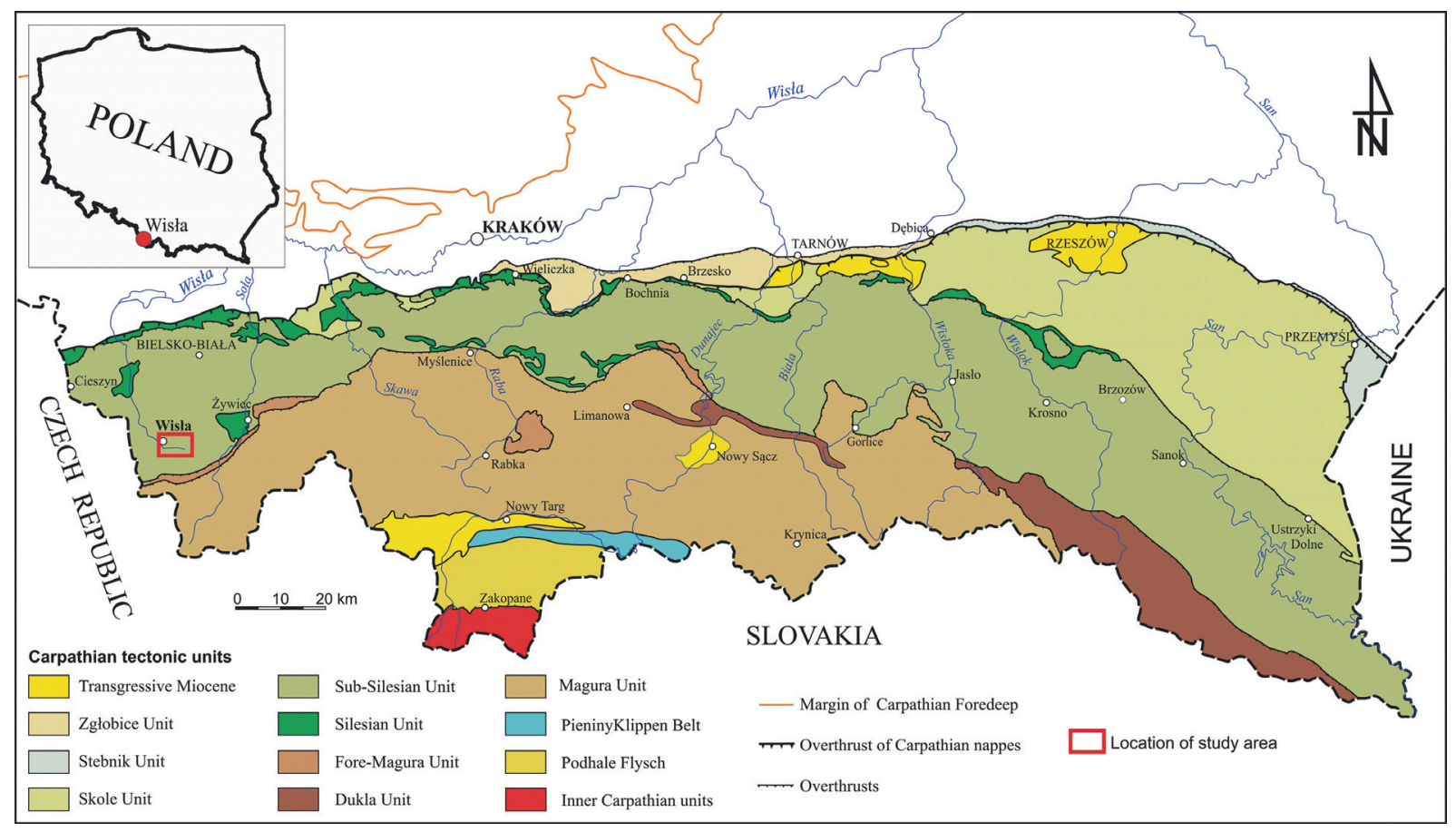

Fig. 1. Location of the study area on the map of the Polish part of the Flysch Carpatians (after Żytko et al. 1989, Oszczypko et al. 2008, simplified) 
The Biała Wisełka Landslide Complex (BWLC) stretches along the southern slope of the Cieńków promontory. The Biała Wisełka Stream flows along the foot of the slope, and its valley separates the Cieńków promontory from the Mt. Barania Góra range in the south.

Geologically, the studied complex is in the area of Silesian Beskid Block of the Outer Carpathians (Fig. 1) (Książkiewicz 1953, 1972), within the Godula Thrust Sheet of the Silesian Nappe (Nowak 1927).

Under the terrain surface there are Upper Cretaceous (Santonian-Campanian - Słomka 1995, Golonka \& Krobicki 2017) sandstones and shales of the Upper Godula Beds (Fig. 2A, B), with an insertion of the Malinów Conglomerate at the top of the beds (Burtan et al. 1937, 1959, Burtan 1972, 1973, Nescieruk \& Wójcik 2016). Sandstones and conglomerates of the Lower Istebna Beds (Campanian \& Unrug 1963, Nescieruk \& Szydło 2003) overlie this complex in a conformable contact. The sandstones and shales of the Upper Godula Beds appear thin-bedded, while the Malinów Conglomerate and Istebna Beds parts of the profile are thick-bedded.

Structurally, the studied area is located on the southern limb of the Szczyrk anticline, where the rock strata are dipping towards the south and south-west at an angle $10-30^{\circ}$ (Fig. 2A, C).

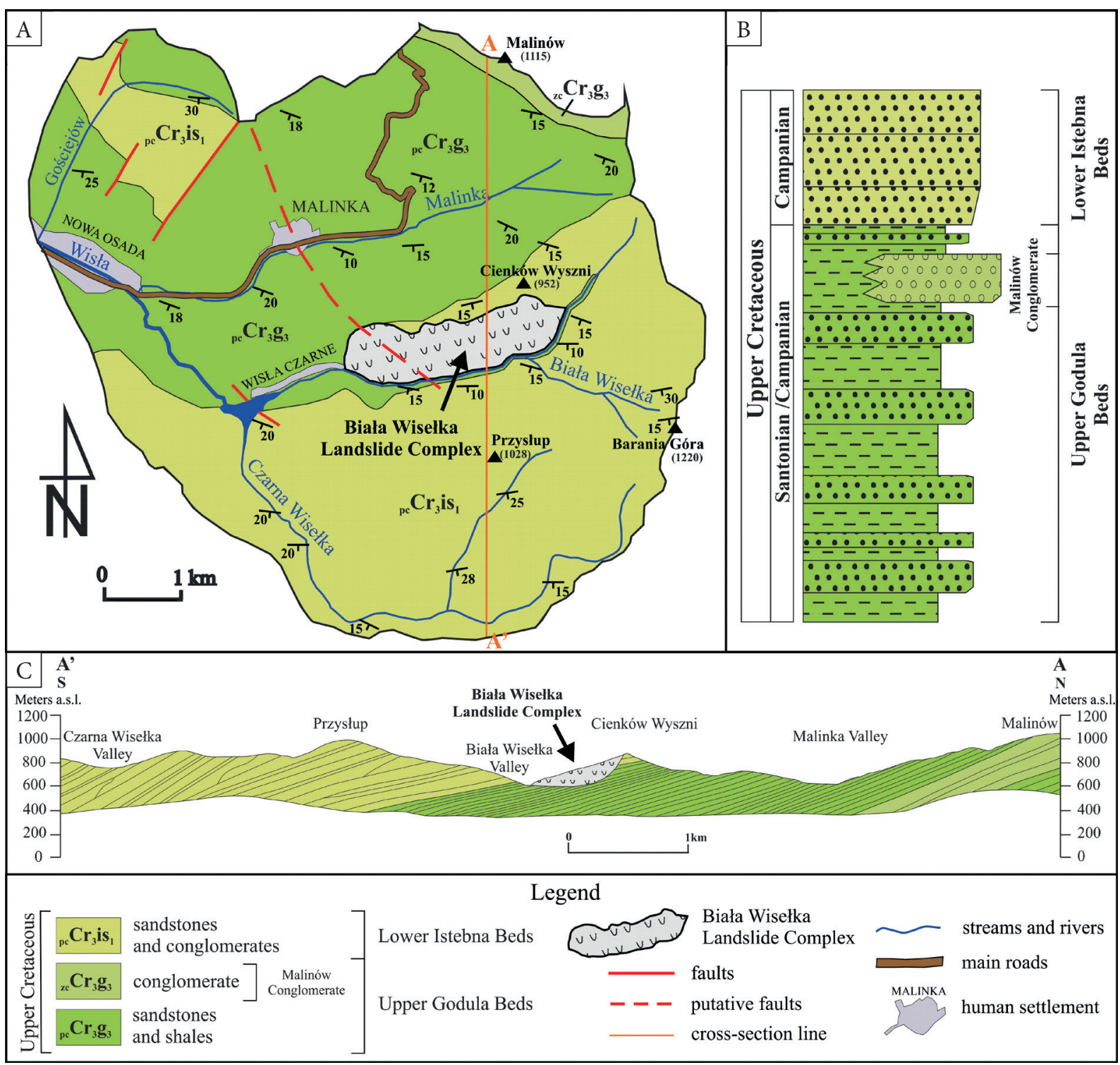

Fig. 2. Geological sketch map of the study area (A); simplified lithostratigraphical profile of the rock series in the study area (B); cross-section of the study area (C) (based on Burtan 1937, 1972, Nescieruk \& Wójcik 2016, simplified) 
As a result of this structural position, the Upper Godula Beds are predominant in the northern part of the area, whereas the southern part rests entirely on the Lower Istebna Beds.

The Detailed Geological Map of Poland at 1:50 $000(\mathrm{SmgP})$ scale, shows several faults at NE-SW, NW-SE and NNW-SSE directions in the research area (Wójcik \& Nescieruk 2016). The longest of them cuts across the central part of the area along a NNW-SSE direction, and its SSE section crosses the western part of the BWLC (Fig. 2A).

The position of the tectonic joint systems respective to folds in the Outer Carpathians has been the subject of studies by, among others, Książkiewicz (1968), Tokarski (1975), Aleksandrowski (1985, 1989) and Mastella et al. (1997). A comprehensive model of the initiation, evolution and final opening of regional and local joint sets and systems in relation to the structural history of folding, thrusting and uplift stages was developed by Aleksandrowski $(1985,1989)$ in the Mt. Babia Góra region of the Magura Nappe. This model, which had expanded Książkiewicz's (1968) earlier results and complemented them with genetic and mechanical explanations, was found to also be applicable in other areas of the Polish Outer Carpathians. It was later applied to the western part of the Silesian Nappe by Mastella and Konon (2002), after changing the nomenclature for some joint systems, and further modified by Tomaszczyk (2005) for the area of the Silesian Beskid by supplementing it with an additional local joint set L" (Fig. 3).

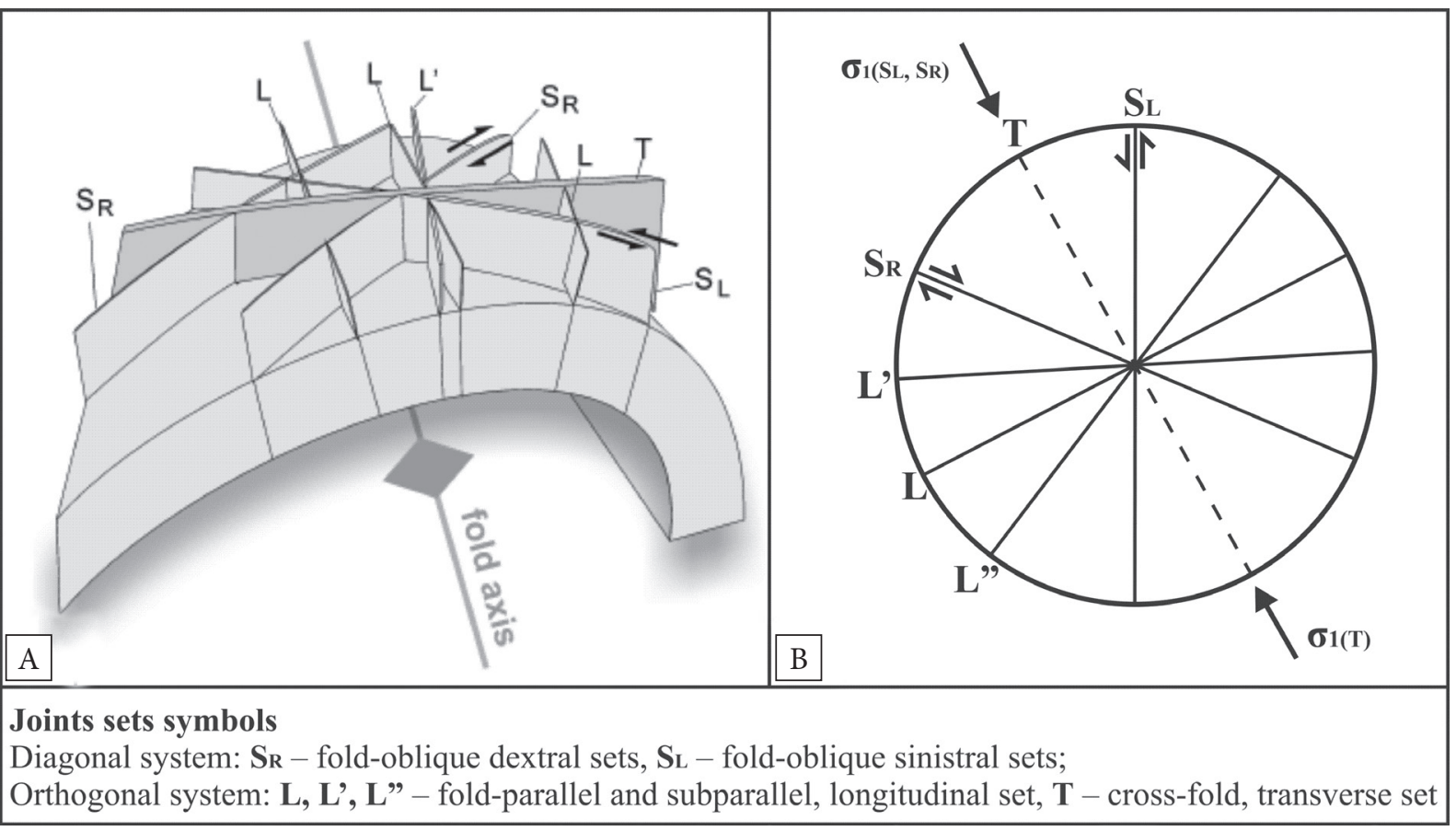

Fig. 3. Joint set system in a folded sandstone layer (after Książkiewicz 1968, modified by Mastella \& Konon 2002) (A); diagrammatic representation of representative joint sets and systems and the position of prefolding $\boldsymbol{\sigma}_{1}$ stress vector in the western part of the Silesian Nappe (after Mastella and Konon 2002, amended by Tomaszczyk 2005) (B)

\section{METHODS}

A map of landslides was elaborated (in accordance with Polish Geological Institute Guidelines, Grabowski et al. 2008) based on site investigations. All tectonic structures (joint sets and systems, faults, minor folds) were also charted by observations and measurements in bedrock outcrops. Particular attention was paid to outcrops located beyond landslide contours and to those exposing the bedrock in landslide escarpments, providing structural information which was unaffected by reorientation due to mass movements. Also recorded were small-scale features on the 
surfaces of joints and faults, such as plumose or concentric structures, slickenside striations, transverse steps on slickensided surfaces and related echelon Riedel cracks etc., that could reveal the kinematics and regime of the bedrock deformation. Parallel to the site investigation, an analysis of the high-resolution digital elevation model (DEM) derived from a LiDAR survey (obtained from ISOK database) was carried out. The analysis was performed using the Global Mapper Ver. 16 program, and considering the suggestions by Ozimkowski (2010) and Wojciechowski (2009) related to the illumination parameters to be used in the model. Morphologically, the objective of DEM analysis was to precisely define the extent and boundaries of the landslides, and their topography elements such as escarpments and tension cracks. The surface features were then interpreted as a reflection of the underlying bedrock structure. For this purpose, the lineaments were identified and marked on the map at 1:10,000 scale, from which the lineaments density chart was derived. A general procedure is presented in Figure 4 (Sikora 2016, 2017). The measurements of the structures identified in the outcrops together with the structures interpreted on DEM were subject to statistical analysis. Rosette strike diagrams, as well as circle and contour plots on Schmidt's stereonet, were produced (using the Fabric 8 program). The obtained results were compared with data known from other studies and with the available maps of landslides.

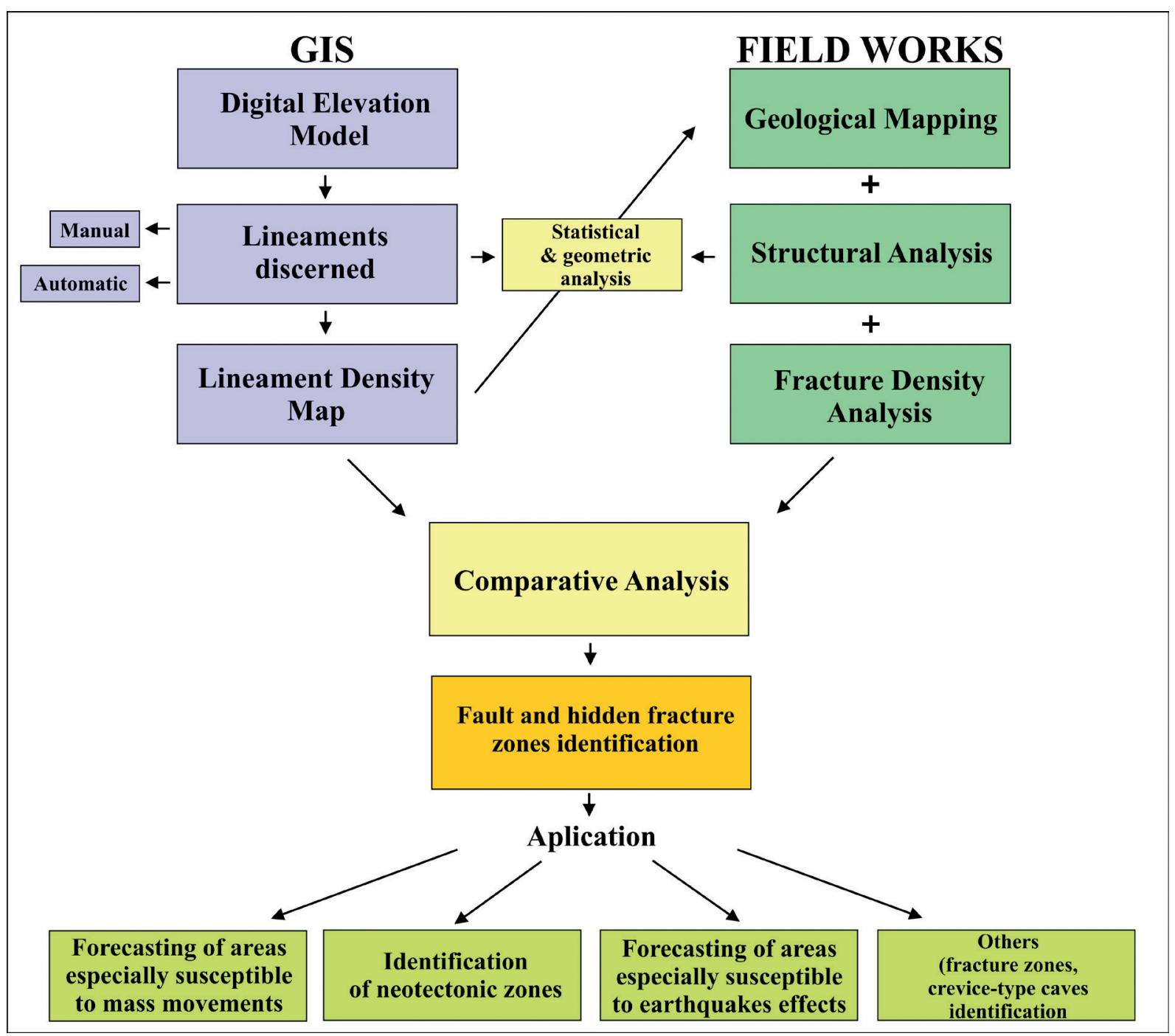

Fig. 4. The applied procedure of the study consisting of various research methods (Sikora 2017) 


\section{RESULTS}

\section{Landslide occurrence in the study area}

There were 172 landslides identified in the $62.50 \mathrm{~km}^{2}$ study area (Fig. 5) (Sikora \& Piotrowski 2013a, 2013b). Considering the area of landslides totaling $14.44 \mathrm{~km}^{2}$, the terrain of the study was subject to intense mass movements. Its landslide index, defined as a ratio of landslide to the total area, is $23 \%$, i.e. one of the highest in the Polish part of the Carpathians. Many of the landslides are very close to each other and difficult to separate them. Therefore, several landslide complexes were identified. The Biała Wisełka Landslide Complex is one of the largest and occupies $2.24 \mathrm{~km}^{2}$ (Fig. 6). The other landslide complexes are, e.g. those of
Czarna Wisełka, Kaskady Rodła, Gościejów and Malinów (Figs. 5, 7).

\section{Characteristics}

\section{of the Biała Wisełka Landslide Complex}

The landslide in the Biała Wisełka valley is one of two marked by Burtan (1972) on map sheet Wisła SmgP. It is further detailed on the landslides map resulting from the SOPO project (Sikora \& Piotrowski 2013a) as a complex of six landslides (Fig. 6).

Therefore, it was categorized as a landslide complex and named the Biała Wisełka Landslide Complex (Sikora 2013). The morphology of the BWLC is well-pronounced when presented on a digital elevation model (Fig. 8), that allowed for the accurate determination of its morphometric parameters (Tab. 1).

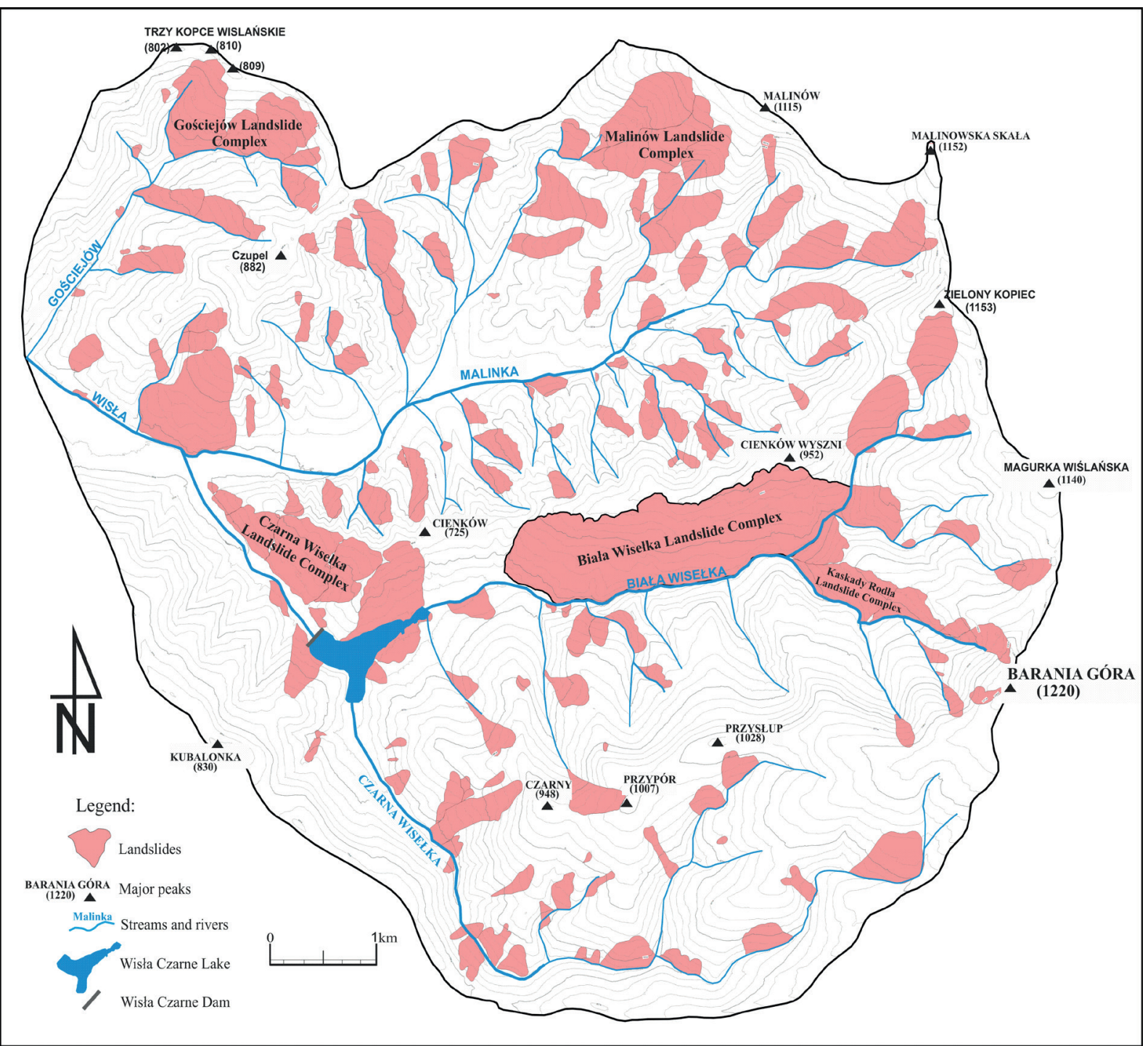

Fig. 5. Sketch map of landslides in the research area (based on Sikora \& Piotrowski 2013, modified) 


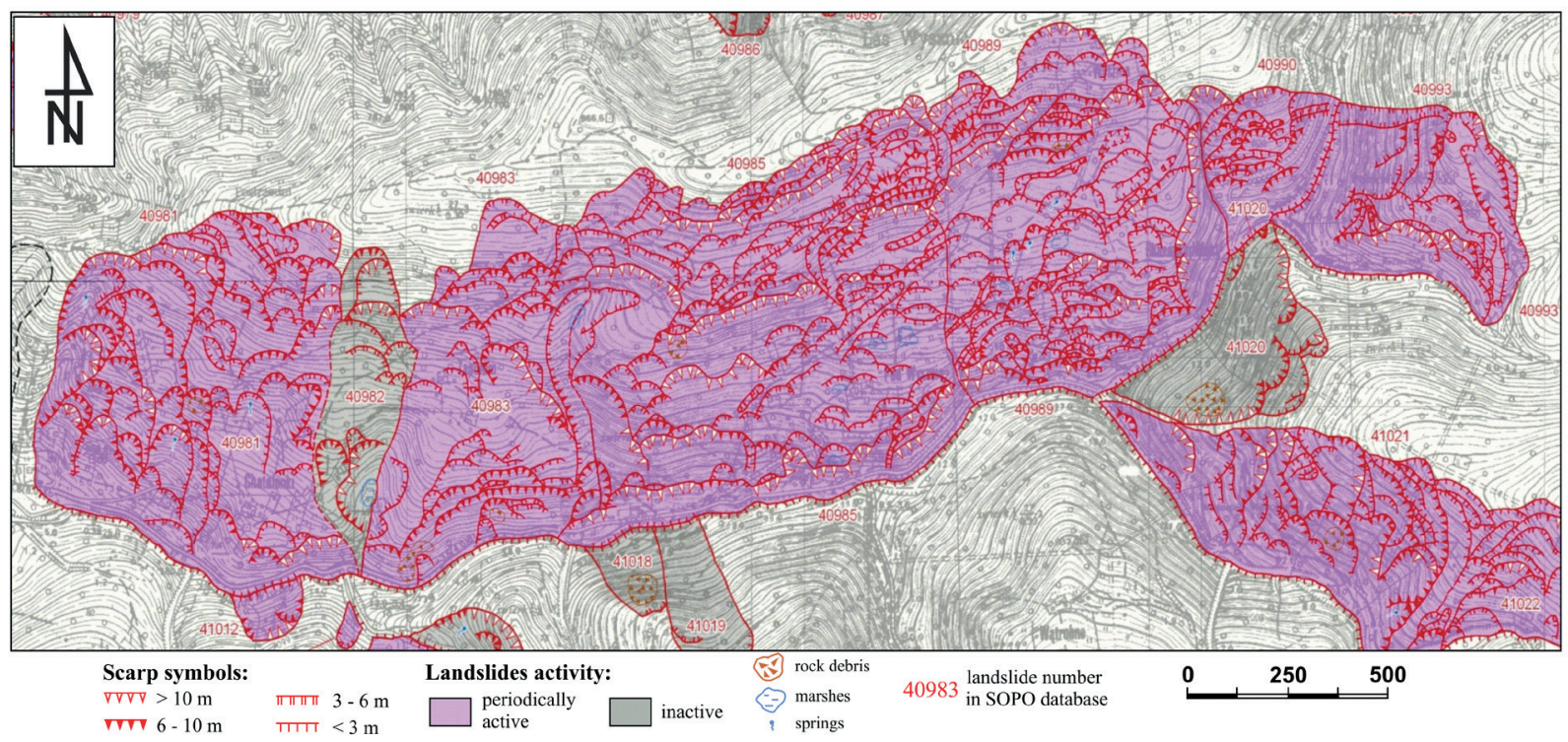

Fig. 6. Detailed map of the Biała Wisełka Landslide Complex

Table 1

Basic morphometric parameters of the Biała Wisetka Landslide Complex calculated using the Digital Elevation Model from Lidar data

\begin{tabular}{|c|c|c|c|c|c|c|c|c|c|c|}
\hline $\begin{array}{c}\text { Area } \\
{\left[\mathbf{k m}^{2}\right]}\end{array}$ & $\begin{array}{l}\text { Peri- } \\
\text { meter } \\
{[\mathrm{km}]}\end{array}$ & $\begin{array}{c}\text { Lenght }^{*} \\
{[\mathrm{~km}]}\end{array}$ & $\begin{array}{l}\text { Width }{ }^{\star} \\
{[\mathrm{kmm}]}\end{array}$ & $\begin{array}{c}\text { Width } \\
\text { to } \\
\text { length } \\
\text { ratio }\end{array}$ & $\begin{array}{c}\text { Azi- } \\
\text { muth }^{*} \\
{\left[{ }^{\circ}\right]}\end{array}$ & $\begin{array}{c}\text { Average } \\
\text { slope } \\
{\left[^{\circ}\right]}\end{array}$ & $\begin{array}{c}\text { Max- } \\
\text { imum } \\
\text { slope } \\
\left.{ }^{\circ}\right]\end{array}$ & $\begin{array}{c}\text { Average } \\
\text { slope } \\
\text { aspect } \\
{\left[^{\circ}\right]}\end{array}$ & $\begin{array}{c}\text { Minimum } \\
\text { elevation } \\
\text { [m a.s.l.] }\end{array}$ & $\begin{array}{c}\text { Maximum } \\
\text { elevation } \\
\text { [m a.s.l.] }\end{array}$ \\
\hline 2.42 & 8.098 & 0.726 & 3.1 & $4: 1$ & 165 & 19 & 90 & 183 & 581 & 919 \\
\hline
\end{tabular}

* In center of landslide axis.

It needs to be highlighted that some sections of the main escarpments reach $40 \mathrm{~m}$ and locally $50 \mathrm{~m}$ of height. Furthermore, there were $360 \mathrm{mi}-$ nor escarpments of various heights identified within the BWLC. The highest of them are located in the upper part of the BWLC and they are approximately parallel to the main escarpment. Tension cracks are frequent at the foot of the highest escarpments. The main and secondary escarpments, as well as the tension cracks, are comparatively long and directed WSW-ENE (Figs. 6, 8). At several locations, the generally straight alignment of the escarpments and cracks abruptly changes to NNW-SSE, which is a predominant direction in the western part of the BWLC. The characteristic morphometric feature of the BWLC is the width to length ratio of 4:1, measured at the axis of the Complex. The geometrical regularity of the escarpments and cracks is apparent on the DEM chart. It is demonstrated further in this paper that this regularity, and the width of the BWLC, are determined by structural elements of the underlying bedrock.

Several types of mass movement effects dating back to the formation stage of the Complex, and of those currently active, were identified within the BWLC. Apart from translational slide features that are easily noticeable in the upper part of the Complex, also identified were the results of other processes, such as rock falling or toppling (Figs. 9, 10). They led to rock debris accumulations; significantly large at some locations (Sikora \& Piotrowski 2013c). Landslide processes are still active in the frontal part of the Complex which toe is more than $10 \mathrm{~m}$ high at some locations. The landslides found within the Complex are classified as a deep-seated category (Hutchinson 1995). The analyses presented further in this paper permits the presumption that the basal slip surfaces are listric and of a cylindrical shape (Fig. 10). This 
shape indicates that a large part of the sliding motion was of the rotational type, whereas the other landslide types mentioned earlier are secondary and occurred after the rotational movement. It should be noted that rotational slip is typical of many large landslides in the Carpathians (Margielewski 2001, 2009). Variability of the slope failure types allows the categorization of the BWLC as a compound landslide (Hutchinson 1995, Crosta 1996, Dikau et al. 1996, Cruden \& Varnes 1996). In accordance with the guidelines for the documentation of landslides (Grabowski et al. 2008), the BWLC can be classified as a complex of rock landslides with a compound (variable) motion whose colluvium consists mainly of detrital blocky rock debris. The compound motion indicates that the sliding motion was parallel to or controlled by genetically different structural features, such as bedding, joints and/or faults. After the proposition of Hungr at al. (2014), the BWLC should be classified as a rock slope deformation.

\section{Structural interpretation}

The generated lineament map and lineaments density map of the research area revealed the existence of the zones of high concentration of lineaments. Superimposing these maps onto the landslides maps exposed the close agreement between the landslide areas and zones with a high density of lineaments (Fig. 7). The BWLC area represents one of the areas showing this coincidence.
The analysis of DEM discerned 526 lineaments on the BWLC area (Fig. 8). The rose diagram shows several prevailing orientations of the lineaments. The comparison of the diagram and the model of the main joint systems in the Silesian Beskids (Fig. 8B) reveals a high correlation between these two. The most prominent lineament directions are WSW-ENE, WWS-EEN and NW-SE that correspond with sets $\mathrm{L}, \mathrm{L}$ ' and $\mathrm{T}$ of the orthogonal joint system (the characters of the nomenclature used for joint sets and systems is assumed after Mastella \& Konon 2002). The lineaments of general NE-SW direction are much less frequent on the strike diagram that corresponds to the joint set L" distinguished by Tomaszczyk (2005), and NNW-SSE direction that agrees with the diagonal joint set $S_{L}$. The joint systems orientation interpreted from DEM is confirmed by measurements in the outcrops conducted on site.

The morphological lineaments of the BWLC, i.e. escarpments and tension cracks, are consistent with the main joint systems. Several of them can be interpreted structurally as fault planes and tension cracks which developed parallel to the joint set $\mathrm{L}$ are associated with them (Figs. 8-10). The genetic link of the landslides escarpments with faults is proved by the length of the rectilinear stretches of the former, reaching in many cases up to $800 \mathrm{~m}$, as well as by their $30-40 \mathrm{~m}$ height, locally reaching $50 \mathrm{~m}$. In addition, the visibly parallel position of the uppermost escarpments likely reflects the presence of several mutually parallel slip planes underneath.

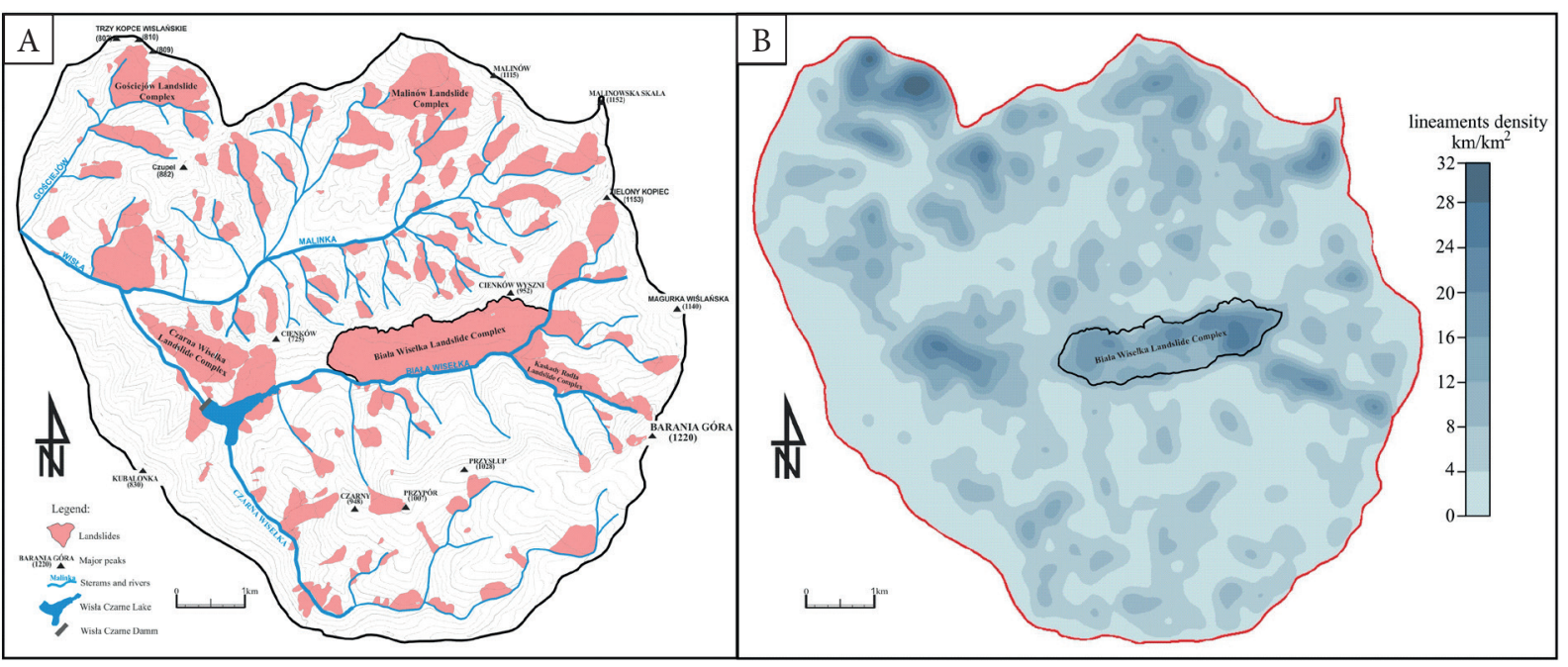

Fig. 7. Comparison of landslide map (A) with that of lineaments density (B) in the research area (Sikora 2017) 


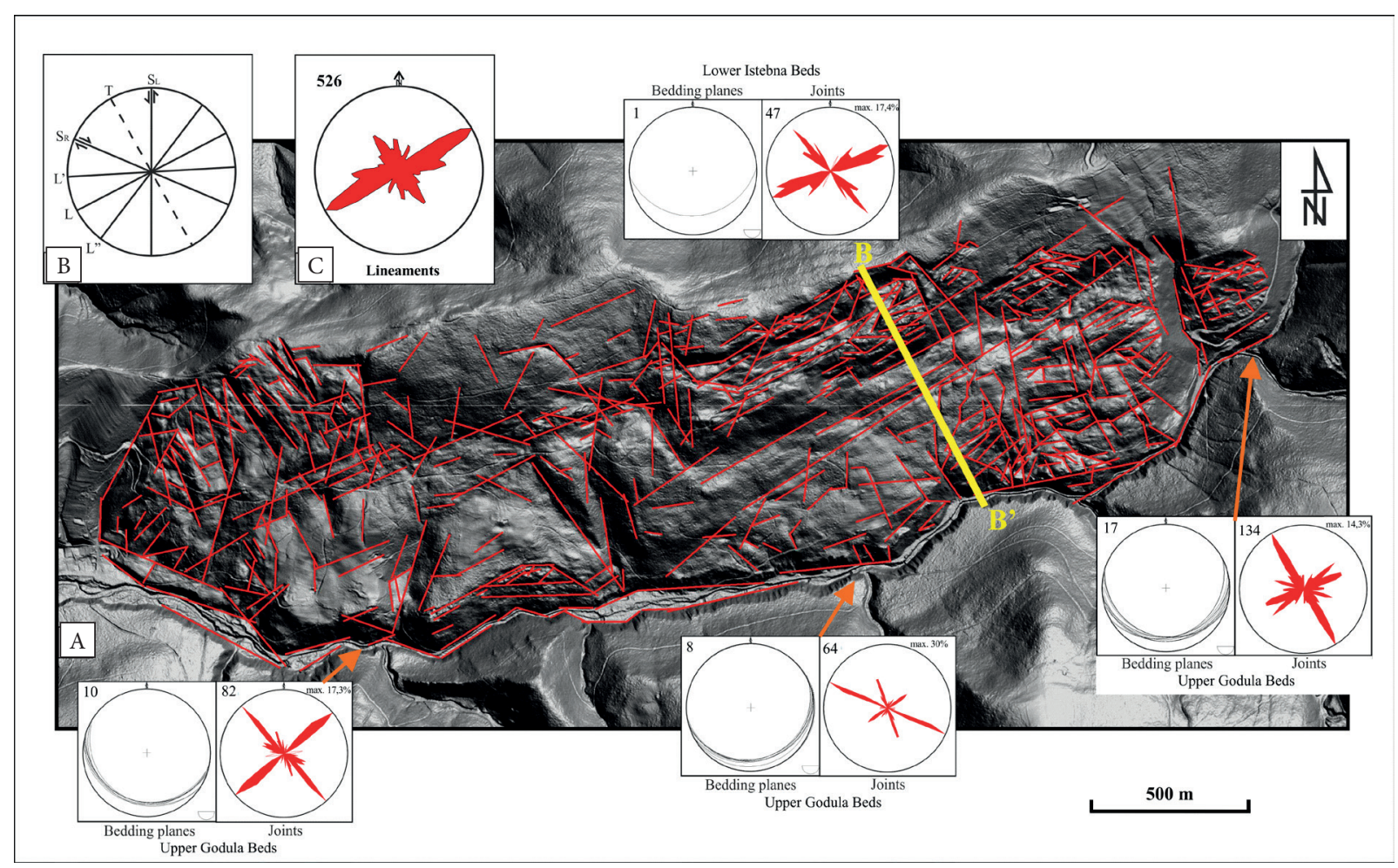

Fig. 8. Digital elevation model (LiDAR-based) of the Biała Wisełka Landslide Complex (BWLC) with lineaments interpretation (A); scheme of regional joint sets orientation in research area (Tomaszczyk 2005) (B); rose diagram of the lineaments orientation in BWLC area (C)

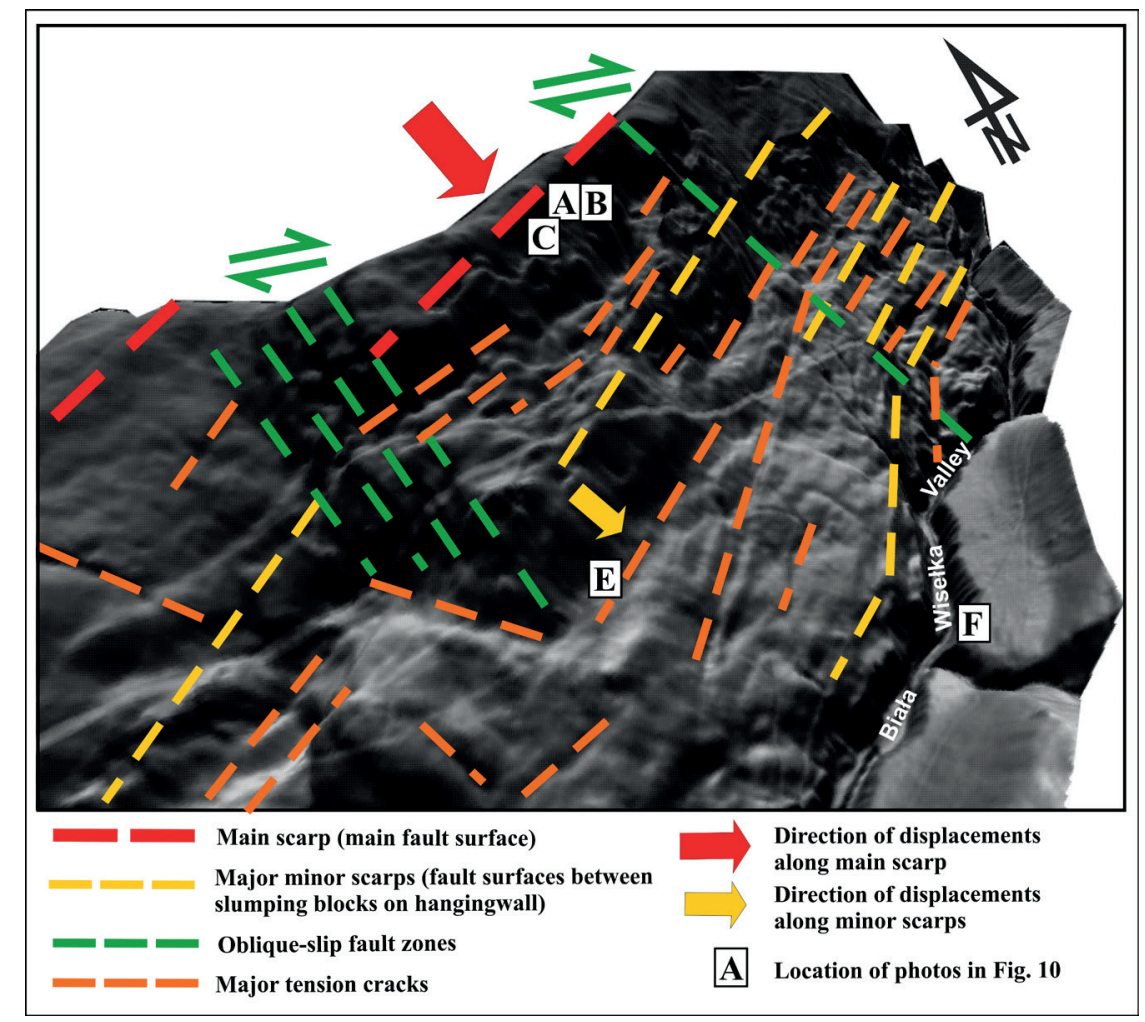

Fig. 9. Structural interpretation of the Biała Wisełka Landslide Complex with examples of geological structures and morphological elements illustrated on DEM based on LiDAR data 
Structurally, the abrupt changes of the strikes of the uppermost escarpments into NW-SE charted are related to the presence of the joint set $\mathrm{T}$, and they are likely to be a result of dextral, normal-slip transformation of the displacements developed along the joint set L. In the text below, the colluvium of the
BWLC is assumed to represent a downthrown side of a normal fault, and the particular colluvium elements to represent blocks downthrown and rotated on secondary slip surfaces. There are eight blocks of this kind interpreted on the hypothetical section across the eastern part of the Complex (Figs. 8, 11).
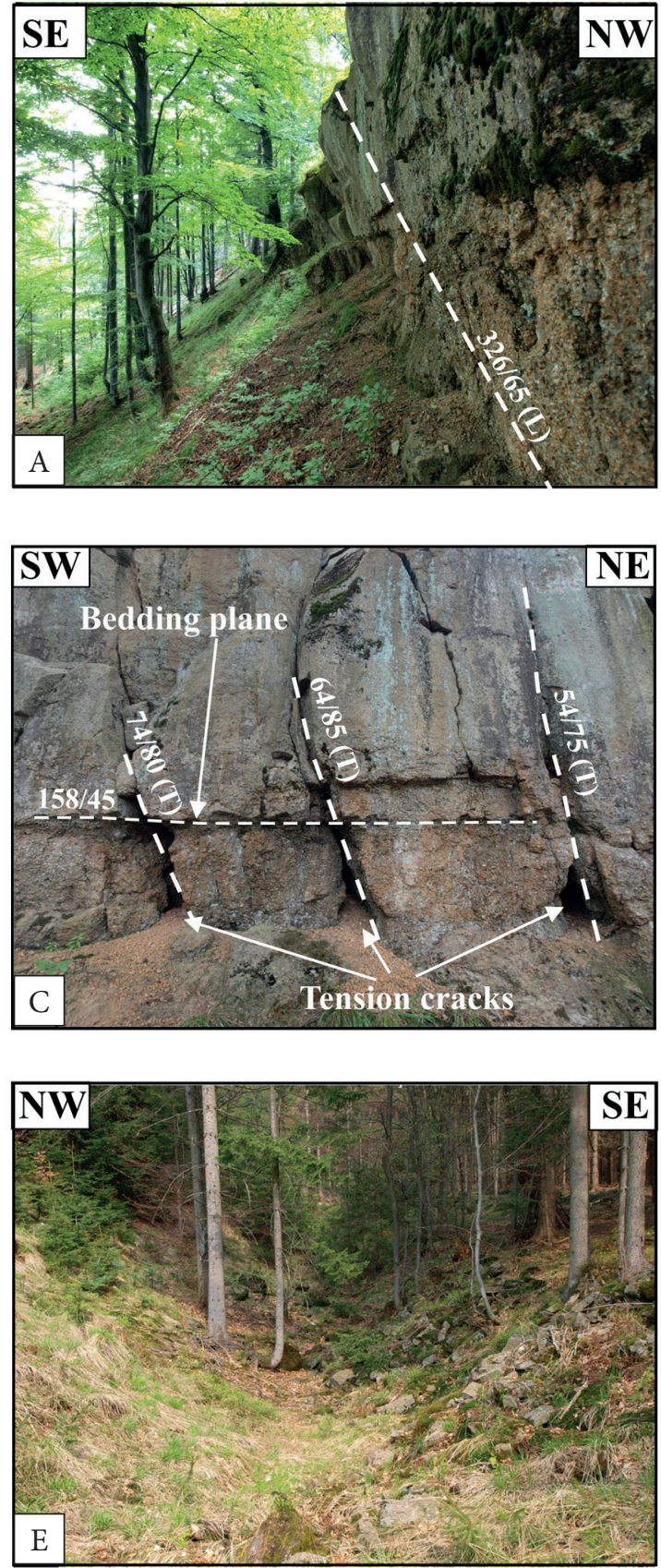
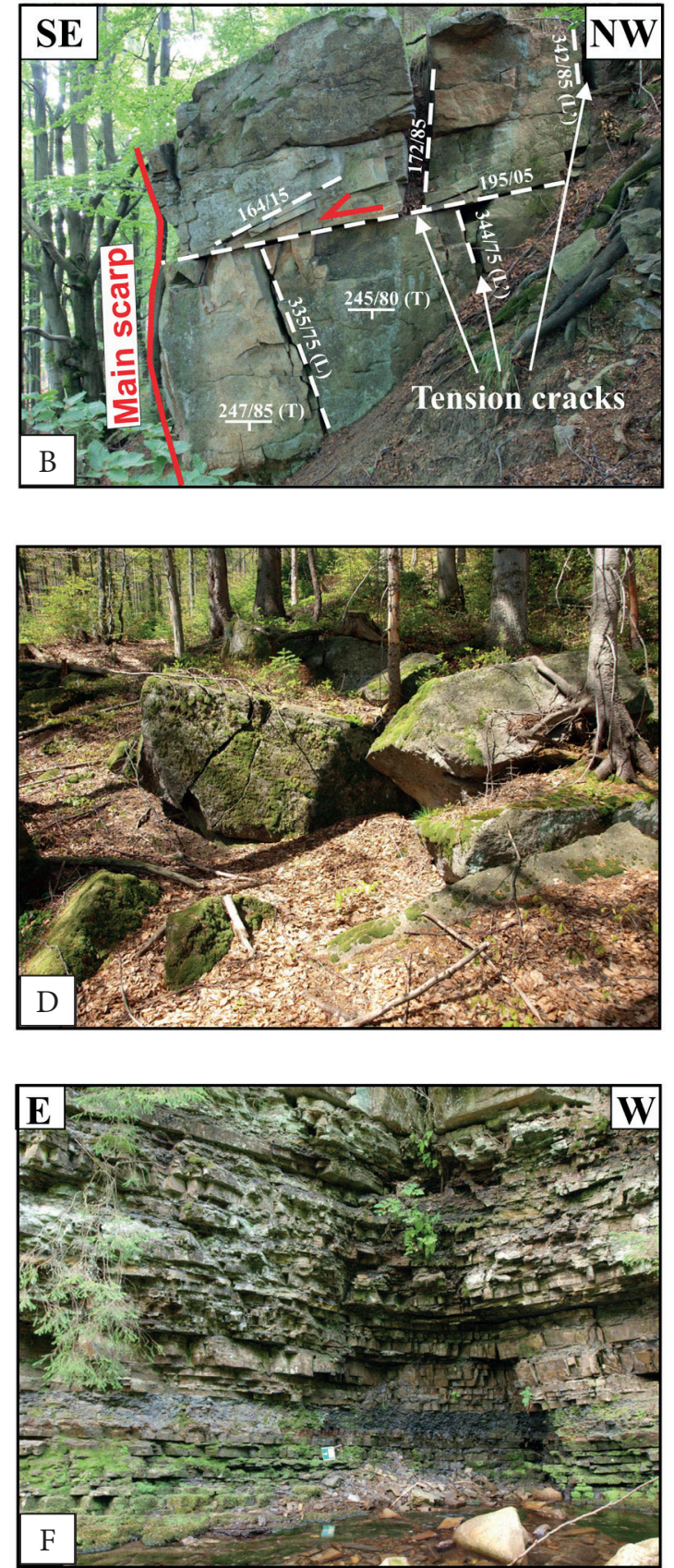

Fig. 10. Photos (located in Figure 9) showing the typical morphological elements of the Biała Wisetka Landslide Complex and bedrock outcrops with tectonic structures. View of the main scarp (main fault surface). Lower Istebna Beds (A). Joints and tension cracks in footwall. Main scarp crosses the section view. Lower Istebna Beds. Red arrow shows present translation sliding direction of the block (B). Fractures and tension cracks on the main scarp surface. Sandstones and conglomerates of the Lower Istebna Beds (C). Blocks of the Lower Istebna sandstones in landslide colluvium (D). Tension crack at the foot of minor scarp (E). Densely cracked rocks of the Upper Godula Beds. Outcrop in front of landslide toe. Biała Wisetka Valley (F) 
This interpretation, together with the inferred shape and extent of the slip surfaces at depth indicates the listric shape of the major and secondary fault slip surfaces. At the deepest parts of the landslides they typically reach slightly below the local erosion base level that varies between 578 and $743 \mathrm{~m}$ a.s.l. at the toe of the Complex. The listric shape of the slip surfaces can explain the rotational displacements of individual blocks in the hanging wall. Based on the kinematics of the landslide processes, a zone of extensional regime can be assumed in the upper part of the BWLC, while in the lower, distal part of the Complex a zone of compressional regime. The extensional conditions manifest themselves in the development of escarpments and cracks, whereas the compression in the distal part led to an accumulation of rock material and the formation of the high front of the landslide (Debacker et al. 2009, Davis et al. 2011).

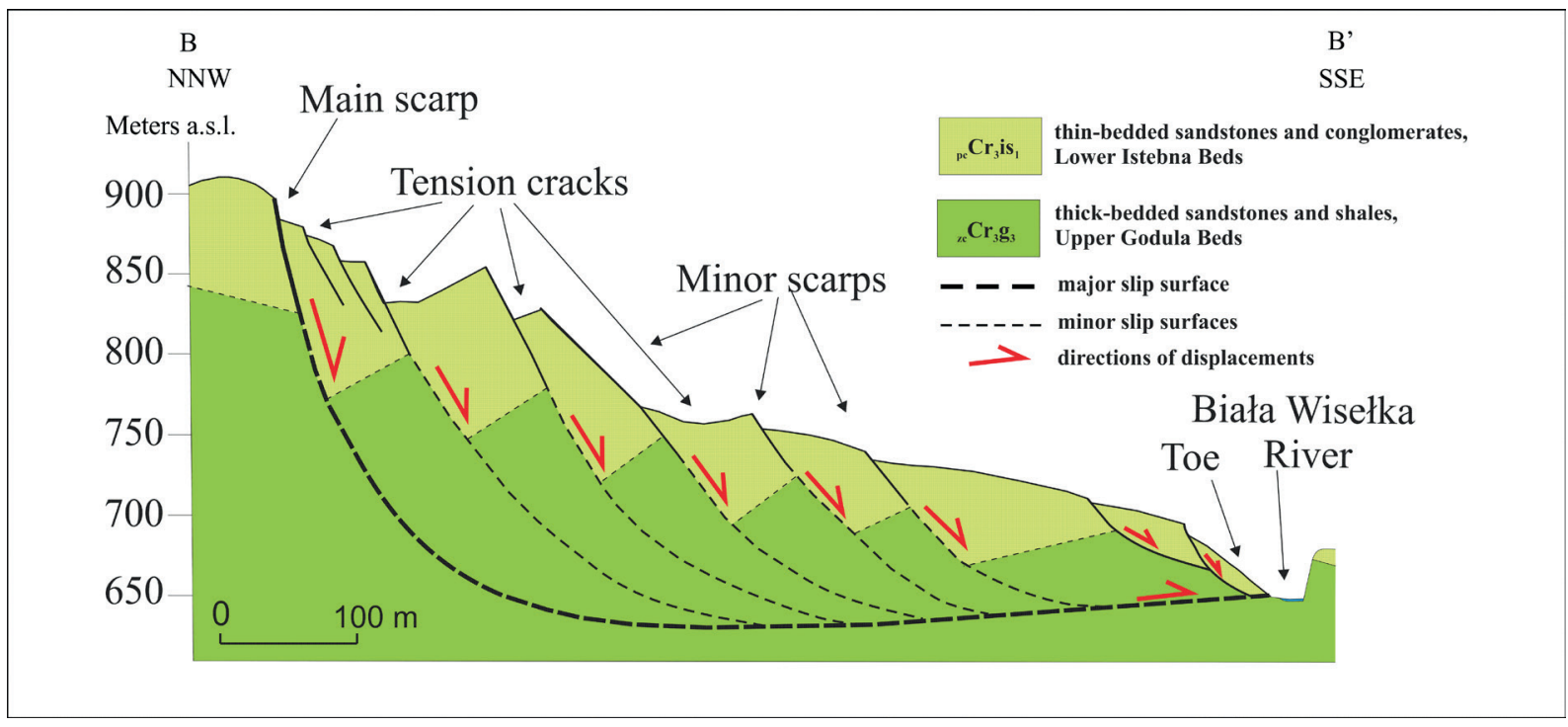

Fig. 11. Structural interpretation of the Biała Wiselka Landslide Complex on a schematic cross-section, assuming a listric nature of the basal teachment and break-away fault, several sliding rotating blocks in the hanging wall

The jointing of the rock mass and conformable position of the rock bedding with respect to the slope, are the factors determining the character of gravitational displacements. Translational slides occur along rock layers, while the steep (locally vertical), up to several tens meters high, rocky escarpments are prone to toppling and rockfalls. The spacing of joints in the Carpathian flysch rocks is generally close to the thickness of the beds (cf. Mastella 1972). This tendency can also be observed in the research area: thin-bedded Upper Godula Beds show well developed, regular and closely spaced jointing, whereas in the thick-bedded Lower Istebna Beds the spacing of joints is much wider. During mass movement, the thick-bedded rock beds resting on thin-layered rock mass undergo fragmentation into blocks. Because of this process, large accumulations of blocky debris are found in the landslide colluvium. The movement of the landslide conforming to the geological structures and the blocky character of the colluvium may lead to the formation of caves within the colluvium. Eleven small voids of the well and shelter types have been documented so far within the BWLC (source: jaskiniepolski.pgi.gov.pl). Broader research on caves in the Silesian Beskids proves the causal link between them, the landslides and the rock massif structure (Tomaszczyk 2005, Margielewski et. al. 2007), hence the presence of larger caves in the BWLC cannot be excluded. Caves are found in many colluvia in the research area. The Miecharska cave on the western slope of the Malinowska Skała and the Wiślańska cave in the Malinów Landslide Complex are the largest known caves in the Polish part of the Flysch Carpathians (Margielewski at al. 2007, 2008, Szura 2007, 2010, Urban et al. 2010). 


\section{DISCUSSION}

Landslide processes result from of a number of factors acting on the slopes. However, they are largely controlled by lithology and the structure of the rock massif. The morphology of slopes affected by landslides in the Carpathians often show escarpments and cracks of characteristic rectilinear strikes. The attempt to determine a relationship between the formation of the Biała Wisełka Landslide Complex, the development of such of its elements as escarpments or tension cracks and the lithology and structure of bedrock yielded positive results. The results were obtained using research methods elaborated specifically for the purpose (Sikora 2016).

A high concentration of lineaments was documented in the BWLC and proved that their orientation corresponding with the regional joint sets. Furthermore, the escarpments and tension cracks in the studied landslide complex reflect the presence of lineaments. Analysis of the site information, available cartographic documentation and the digital elevation model (on GIS platform) obtained from LiDAR survey proved the relationships to be very strong. According to Aleksandrowski $(1985,1989)$ the jointing systems in the Outer Western Carpathians formed (were initiated) due to shearing $\left(\mathrm{S}_{\mathrm{L}}\right.$ and $\mathrm{S}_{\mathrm{T}}$ sets) and contraction/extension (L, L' and T sets), caused by early, folding-related layer-parallel shortening of the rock strata. The strain effects were stored in the deeply buried rocks mostly as structural anisotropy directions defined by preferentially oriented trains of microcracks. After the folding and during syn- and late-orogenic uplift, the joints massively developed at shallow depths as extensional features, propagating along the microcrack trains. As such, they constitute natural structural planes along which the rock mass splits under gravitational forces. As a consequence, the mountain slopes with bedrock showing high intensity of jointing are particularly susceptible to the development of faults and landslides. The resulting rock mass displacements tend to follow the local directions of the present-day minimum compressive or tensile stress $\sigma_{3}(\mathrm{NW}$ $\mathrm{SE}$ ), which, at very shallow levels is directed downslope. In the study area, these directions are often aligned parallel to the maximum compressive palaeostress direction $\sigma_{1}$ (Fig. $3 \mathrm{~B}$ ) that was active before the folding stage, i.e. when the rock beds were still in a horizontal position (Early Miocene?; cf. Książkiewicz 1972, Aleksandrowski 1985, 1989, Oszczypko 1998, Mastella \& Konon 2002).

The above presented research results highlight the role of passive factors (lithology and bedrock structure) in the development of the landslides. These results may become crucial for understanding this role in the broader aspect of the Silesian Beskid. For this purpose, similar analyses need to be carried out on the remaining landslides and landslide complexes in the area. Further verification of the conclusions, if positive, would allow their extrapolation and the application of the developed methodology over the entire area of the Outer Carpathians. The application of the proposed methodology in others areas allows the identification of its imperfections and limitations as a result of a various factors, e.g. differences between scale of GIS analysis and scale of observed mass movements or complexity of the analyzed geological structures. On this basis, it will be possible to improve it.

The problem that needs further study is the identification of the factors that initiated slope mass movements at such a large scale as that documented in the Silesian Beskid. They usually took place mostly at the end of the Pleistocene and the beginning of the Holocene (Starkel 1960, Gil at al. 1974, Alexandrowicz 1978, Margielewski 1998a, 2001b) and may have been triggered by permafrost recession. However, other factors cannot be excluded, especially considering that many of the landslides were later reactivated (Jakubowski 1967, Wójcik 1997). The next stage of the research is planned in order to reveal the potential influence of isostasy, seismicity and neotectonic phenomena in the region on initiating mass movements. The significant role of seismicity in affecting the stability of slopes and activating landslides in the Silesian Beskid can be suspected from the fact that its area belongs to Seismic Zone IV of Poland where the magnitude of recorded earthquakes was up to $6^{\circ}$ in the EMS-98 scale (Fig. 12A) (Guterch 2009). As shown in Figure 12B, it is a region of high earthquake hazard, prone to seismic events reaching up to $7^{\circ}$ or more in MSK scale (Schenk et al. 2001). Historical records from between the $15^{\text {th }}$ and $19^{\text {th }}$ centuries show earthquake 
magnitudes higher than $4.3 \pm 0.4$ in the Wisła area (Pagaczewski 1972). By comparing the earthquake effects (landslides) in the Silesian Beskids and those in Italy in 2016 (Norcia Earthquake, magnitude 5.9-6.5, Martino at al. 2016, Wilkinson at al. 2017), and New Zealand (Kaikoura Earthquake, magnitude 7.8, Dellow \& Massey 2017), it can be supposed that the earthquakes in the Beskids were even stronger. Gerlach et al. (1958), Bober \& Oszczypko (1975), Bober \& Wójcik (1977), Mastella (1978), Bober (1984), Wójcik (1997), Poprawa \& Rączkowski (2003) and Rączkowski (2007) also indicated seismicity and neotectonics as important factors initiating the landslides in the Carpathians.

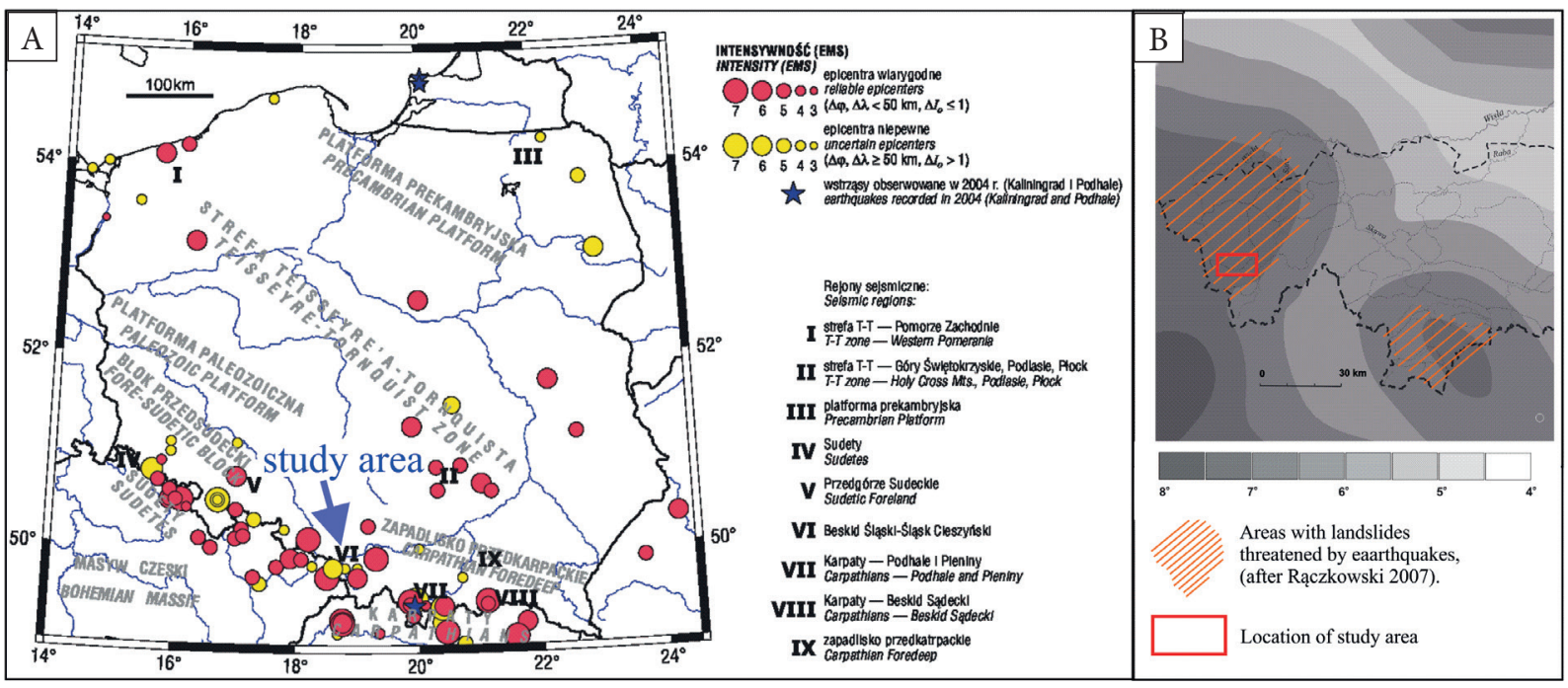

Fig. 12. Location of the study area on the earthquake epicentres map in Poland (EMS-98 scale, Guterch 2009) (A); location of the study area on the earthquake hazard chart (scale of MSK, after Schenk et al. 2001, Raczkowski 2007) of the western part of Polish Carpathians (B)

\section{CONCLUSION}

The research on the Biała Wisełka Landslide Complex confirmed that it represents a compound landslide type and its origin has been structurally controlled. Such types of landslides predominate among the Carpathian deep-reaching landslides (Margielewski 2001a). Besides the climatological factor, the seismicity of the region and neotectonic phenomena might have contributed to its development by splitting and fragmenting the rock strata (Zuchiewicz 1995, 1999).

Whatever the causes of the fragmentation of strata and the triggering of mass movements, the resulting features, such as escarpments and tension cracks, mimic the structure of the underlying bedrock. The Biała Wisełka Landslide Complex formed along a lineament of ENE-WSW strike, and it's parallel to the axis (L) of a regional-scale fold. This lineament correlates with the strike of the existing normal fault of a listric slip surface. The BWLC also underwent further segmentation along NW-SE trending lineaments (corresponding to the joint set T). The secondary, lower-order escarpments formed as a result of displacement and the drop of blocks within the hanging wall of the main detachment fault. The tensional cracks were formed at the foot of the uppermost escarpments.

Based on the investigated relationships between landslide development and the bedrock structure, one can confirm the intuitive idea that areas with high concentrations of lineaments are particularly susceptible to slope mass movements. The landslides can be activated and reactivated by various neotectonic processes and are particularly endangered by earthquakes. The investigated relationship between the bedrock structure and landslide development on slopes also offers a methodology for detecting fault and damage zones concealed below the slope debris and mass movement deposits. 
I would like to thank Professor Antoni Wójcik and my reviewers Professor Pawet Aleksandrowski, Dr Arben Kociu and Dr Petr Tábořík for their criticism, constructive comments and suggestions. All the remarks were very helpful in substantially improving the paper.

The research has been funded and supported by the Polish Geological Institute - National Research Institute, project No. 61.2306.1201.00.0.

\section{REFERENCES}

Aleksandrowski P., 1985. Structure of the Mt. Babia Góra region, Magura Nappe, Western Outer Carpathians: An interference of West and East Carpathian fold trends. Annales Societatis Geologorum Poloniae, 55, 375-422.

Aleksandrowski P., 1989. Geologia strukturalna płaszczowiny magurskiej w rejonie Babiej Góry. Studia Geologica Polonica, 96, 7-149.

Alexandrowicz S.W., 1978. The northern slope of Babia Góra Mt. as a huge rock slump. Studia Geomorphologica Carpatho-Balcanica, 12, 133-148.

Bajgier-Kowalska M., 1996. Role of deep transversal dislocation in development of landslides in the flysch Carpathians. [in:] Senneset K. (ed.), Landslides, Proceedings of the 7th International Symposium on Landslides, Trondheim, Norway, 17-21 June 1996, Balkema, Rotterdam, 1847-1851.

Bober L., 1984. Rejony osuwiskowe w polskich Karpatach fliszowych i ich związek z budową geologiczną rejonu. Biuletyn Instytutu Geologicznego, 340, 23, 115-161.

Bober L., 1990. Monografia osuwisk karpackich. Narodowe Archiwum Geologiczne - PIG-PIB, Kraków.

Bober L. \& Oszczypko N., 1975. On geological conditions of structural landslides occurrences in the Polish Flysch Carpathians. [in:] Proceedings of the $X^{\text {th }}$ Congress, Carpatho-Balkan Geological Association, Section 3, Tectonics, Geologický ústav Dionýza Štúra, Bratislava, 38-45.

Bober L. \& Wójcik A., 1977. Structural landslides in the region of the Prusów Ridge (Beskid Żywiecki Mts.). Studia Geomorphologica Carpatho-Balcanica, 11, 155-167.

Burtan J., 1972. Szczegółowa mapa geologiczna Polski. Arkusz Wisła 1:50 000. Wydawnictwa Geologiczne, Warszawa.

Burtan J., 1973. Objaśnienia do Szczegółowej mapy geologicznej Polski. Arkusz Wisła 1:50 000. Wydawnictwa Geologiczne, Warszawa.

Burtan J., Konior K. \& Książkiewicz M., 1937. Mapa geologiczna Karpat polskich. Polska Akademia Umiejętności, Kraków.

Burtan J., Sokołowski S., Sikora W. \& Żytko K., 1959. Szczegółowa mapa geologiczna Polski. Arkusz Milówka 1:50 000. Wydawnictwa Geologiczne, Warszawa.

Cała M., 2009. Osuwiska w Polsce i na świecie. Nowoczesna Budownictwo Inżynieryjne, 3, 68-74.

Crosta G., 1996. Landslide, spreading, deep seated gravitational deformation: analysis, examples, problems and proposal. Geografia Fisica e Dinamica Quaternaria, 19, 297-313.
Cruden D.M. \& Varnes D.J., 1996. Landslide types and processes. [in:] Turner A.K. \& Schuster R.L. (eds.), Landslides: investigation and mitigation, Transportation Research Board. National Research Council. Special report, 247, National Academy Press, 36-75.

Davis G.H., Reynolds S.J. \& Kluth C.F., 2011. Structural Geology of Rocks and Regions. $3^{\text {rd }}$ ed. John Wiley and Sons, New York.

Debacker T.N., Dumon M. \& Matthys A., 2009. Interpreting fold and fault geometries from within the lateral to oblique parts of slumps: a case study from the Anglo-Brabant Deformation Belt (Belgium). Journal of Structural Geology, 31, 1525-1539.

Dellow S. \& Massey C., 2017. Kaikoura Earthquake - Landslide dams: identifying the hazard and managing the risks. NZ Geomechanics News, 93, [on-line:] http:// www.nzgs.org/library/kaikoura-earthquake-landslidedams-identifying-the-hazard-and-managing-the-risks/ [access: 08.03.2018].

Dikau R., Brunsden D., Schrott L. \& Ibsen M.L. (eds.), 1996. Landslide Recognition: Identification, Movement and Causes. Wiley, New York.

Gerlach T., Pokorny J. \& Wolnik R., 1958. Osuwisko w Lipowicy. Przegląd Geograficzny, 30, 4, 685-700.

Gil E., Gilot E., Kotarba A., Starkel L. \& Szczepanek K., 1974. An early Holocene landslide in the Beskid Niski and its significance for paleogeographical reconstruction. Studia Geomorphologica Carpatho-Balcanica, 23, 139-152.

Golonka J. \& Krobicki M., 2017. The Position of the West Carpathians in the Alpine-Carpathian Fold-And-Thrust Belt. [in:] Krobicki M. (ed.), $6^{\text {th }}$ International symposium of the international geoscience programme (IGCP) project-589: development of the Asian Tethyan Realm: genesis, process and outcomes: Western Tethys meets Eastern Tethys: Kraków (Poland), 29 September-5 October 2017: abstract volume \& field trip guidebook, Polish Geological Institute - National Research Institute, Warsaw, 63-65.

Grabowski D., Marciniec P., Mrozek T., Nescieruk P., Rączkowski W., Wójcik A. \& Zimnal Z., 2008. Instrukcja opracowania Mapy osuwisk i terenów zagrożonych ruchami masowymi w skali 1: 10 000. Państwowy Instytut Geologiczny, Warszawa.

Guterch B., 2009. Sejsmiczność Polski w świetle danych historycznych. Seismicity in Poland in the light of historical records. Przeglad Geologiczny, 57, 513-520.

Hungr O., Leroueil S. \& Picarelli L., 2014. The Varnes classification of landslide types, an uptade. Landslides, 11, $2,167-194$

Hutchinson J.N., 1995. Deep-seated mass movements on slopes. Memorie della Società Geologica Italiana, 50, 147-164.

Jakubowski K., 1967. Badania nad przebiegiem wtórnych przeobrażeń form osuwiskowych na obszarze fliszu karpackiego. Prace Muzeum Ziemi, 11, 223-242.

Książkiewicz M. (red.), 1953. Regionalna geologia Polski, t. 1, Karpaty, z. 2, Tektonika. Polskie Towarzystwo Geologiczne, Kraków, 362-422.

Książkiewicz M., 1968. Spostrzeżenia nad rozwojem ciosu w Karpatach fliszowych. Rocznik Polskiego Towarzystwa Geologicznego, 38, 2-3, 335-384. 
Książkiewicz M., 1972. Budowa geologiczna Polski. T. 4, Tektonika. Cz. 3, Karpaty. Wydawnictwo Geologiczne, Warszawa.

Margielewski W., 1998a. Landslide phases in the Polish Outer Carpathians and their relation to climatic changes in the Late Glacial and the Holocene. Quaternary Studies in Poland, 15, 37-53.

Margielewski W., 1998b. Rozwój form osuwiskowych w Baranowcu (Beskid Sądecki, Karpaty zewnętrzne), w świetle analizy strukturalnych uwarunkowań osuwisk w Karpatach fliszowych [Development of landslide forms in Barnowiec (Beskid Sądecki Mts, Outer Carpathians) in the light of the analysis of structural background of the landslides in the Flysch Carpathians]. Przeglad Geologiczny, 46, 5, 436-452.

Margielewski W., 2001. O strukturalnych uwarunkowaniach rozwoju głębokich osuwisk - implikacje dla Karpat fliszowych [About the structural control of deep landslides. Implications for the Flysch Carpathians (southern Poland)]. Przeglad Geologiczny, 49, 6, 515-524.

Margielewski W., 2001. Late Glacial and Holocene climatic changes registered in forms and dposits of the Klaklowo landslide (Beskid Średni Range, Outer Carpathians). Studia Geomorphologica Carpatho-Balcanica, 35, 63-79.

Margielewski W., 2002. Geological control on the rocky landslides in the Polish Flysch Carpathians. Folia Quaternaria, 73, 53-68.

Margielewski W. 2004., Typy przemieszczeń grawitacyjnych mas skalnych w obrębie form osuwiskowych polskich Karpat fliszowych. Przeglad Geologiczny, 52, 7, 603-614.

Margielewski W., 2006. Structural control and types of movements of rock mass in anisotropic rocks: Case studies in the polish Flysch Carpathians. Geomorphology, 77, 47-68.

Margielewski W., 2009. Problematyka osuwisk strukturalnych w Karpatach fliszowych w świetle zunifikowanych kryteriów klasyfikacji ruchów masowych - przegląd krytyczny. Przegląd Geologiczny, 57, 905-917.

Margielewski W. \& Urban J., 2000. Charakter inicjacji ruchów masowych w Karpatach fliszowych na podstawie analizy strukturalnych uwarunkowań rozwoju wybranych jaskiń szczelinowych. Przegląd Geologiczny, 47, 268-274.

Margielewski W. \& Urban J., 2003. Crevice-type caves as initial forms of rock landslide development in the Flysch Carpathians. Geomorphology, 54, 3-4, 325-338.

Margielewski W., Urban J. \& Szura Cz., 2007. Jaskinia Miecharska cave case study of a crevice-type cave developed on a sliding surface. Nature Conservation, 63, 57-68.

Margielewski W., Szura C. \& Urban J., 2008. Jaskinia Miecharska cave (Beskid Śląski Mts., Outer Carpathians) The largest non-karst cave in the Flysch Carpathians. Zacisk: Polskie Towarzystwo Turystyczno-Krajoznawcze. Oddział Bielsko-Biała, Klub Taternictwa Jaskiniowego "Speleoklub", spec. issue, 7-13.

Mastella L., 1972. Interdependence of joint density and thickness of layers in the Podhale Flysch. Bulletin de L'Academie Polonaise des Sciences. Série des sciences de la Terre, 20, 187-196.

Mastella L., 1975. Osuwiska konsekwentno-strukturalne na Podhalu. Biuletyn Geologiczny Uniwersytetu Warszawskiego, 18, 259-270.
Mastella L., Zuchiewicz W., Tokarski A.K., Rubinkiewicz J., Leonowicz P. \& Szczęsny R., 1997. Application of joint analisys for paleostress reconstruction in structurally complicated settings: case study from Silesian nappe, Outer Carpathians (Poland). Przeglad Geologiczny, 10/2, 1064-1066.

Mastella L. \& Konon A., 2002. Jointing in the Silesian Nappe (Outer Carpathians, Poland) - paleostress reconstruction. Geologica Carpathica, 53, 5, 315-325.

Martino S., Bozzano F., Caporossi P., Della Seta M., Esposito C., Fantini A., Fiorucci M., Iannucci R., Marmoni G.M., Mazzanti P., Moretto S., Rivellino S., Romeo R.W., Sarandrea P., Troiani F. \& Varone C., 2016. Landslides triggered by the August 24, 2016 (Mw 6.0) Amatrice earthquake (Italy): data survey and inventorying. [in:] GNGTS 35 convegno nazionale, Riassunti estesi delle comunicazioni 2016, 22-24 November, 2016, Lecce, Italia, 55-58, [on-line:] www3.ogs.trieste.it/gngts/files/2016/ SSp/Riassunti/Martino.pdf [access: 08.03.2018].

Nemčok A., 1982. Zosuwy v Slovenskych Karpatach. VEDA, Bratislava.

Nescieruk P. \& Szydło A., 2003. Pozycja warstw istebniańskich w Beskidzie Morawsko-Śląskim. Posiedzenia Naukowe Państwowego Instytutu Geologicznego, 60, 67-68.

Nescieruk P. \& Wójcik A., 2016. Szczegółowa mapa geologiczna Polski. Arkusz Wisła 1:50 000 (reambulacja). Narodowe Archiwum Geologiczne, Warszawa.

Nowak J., 1927. Zarys tektoniki Polski. [in:] II Zjazd Słowiańskich Geografów i Etnografów w Polsce, 2-12 czerwca 1927, Komitet Organizacyjny II. Z.S.G.E., Kraków.

Oszczypko N., 1998. The Western Carpathian Foredeep development of the foreland basin in front of the accretionary wedge and its burial history (Poland). Geologica Carpathica, 49, 6, 415-431.

Oszczypko N., Ślączka A. \& Żytko K., 2008. Regionalizacja tektoniczna Polski - Karpaty zewnętrzne i zapadlisko przedkarpackie. Przeglad Geologiczny, 56, 10, 927-935.

Ozimkowski W., 2010. Wpływ kierunku iluminacji na wyniki geologicznej interpretacji DEM - przykłady z Karpat Zachodnich. Przeglad Geologiczny, 58, 9/2, 862-866.

Pagaczewski J., 1972. Catalogue of earthquakes in Poland in 1000-1970 [Katalog trzesięn ziemi w Polsce $z$ lat 10001970]. Materiały i Prace - Polska Akademia Nauk. Instytut Geofizyki, 51, Państwowe Wydawnictwo Naukowe, Warszawa.

Pánek T., Margielewski W., Táboř́́k P., Urban J., Hradecký J. \& Szura C., 2010. Gravitationally induced caves and other discontinuities detected by 2D electrical resistivity tomography: Case studies from the Polish Flysch Carpathians. Geomorphology, 123, 165-180.

Pánek T., Tábořík P., Klimeš J., Komárková V., Hradecký J. \& Štastný M., 2011. Deep-seated gravitational slope deformations in the highest parts of the Czech Flysch Carpathians: Evolutionary model based on kinematic analysis, electrical imaging and trenching. Geomorphology, 29, 92-112.

Poprawa D. \& Rączkowski W, 2003. Osuwiska Karpat. Przegląd Geologiczny, 51, 8, 685-692.

Rączkowski W., 2007. Landslides hazard in the Polish Flysch Carpathians. Studia Geomorphlogica Carpatho-Balcanica, 26, 61-75. 
Schenk V., Schenková Z., Kottnauer P., Guterch B. \& Labák P., 2001. Earthquake hazards maps for the Czech Republic, Poland and Slovakia. Acta Geophisica Polonica, $49,3,287-302$.

Sikora R., 2014. Structural conditions of landslides development in the Biała Wisełka Valley (Silesian Beskid, Outer Carpathians). Geologia Sudetica, 42, 85.

Sikora R., 2014. Structural origin of landslides in the Vistula River source area (Silesian Beskid, Outer Carpathians, Poland). [in:] Proceedings, XX Congress of the Carpathian-Balkan Geological Association, September 23-26, 2014, Tirana, Albania, Buletini i Shkencave Gjeologjike, special issue, 1,470 .

Sikora R., 2015. Rola struktury podłoża w powstawaniu osuwisk na przykładzie rejonu Baraniej Góry (Beskid Śląski). [in:] Kalinowska A. \& Zawada P. (red.), Ogólnopolska Konferencja O!suwisko: 19-22 maja 2015, Wieliczka: materiały konferencyjne, Państwowy Instytut Geologiczny - Państwowy Instytut Badawczy, Warszawa, 67-68.

Sikora R., 2016. Identyfikacja ukrytych uskoków i stref zniszczenia w obszarze bloku Beskidu Śląskiego w oparciu o badania strukturalne, analizę lineamentów i wysokościowy model terenu (z danych LiDAR). [in:] Wojewoda J. \& Kowalski A. (red.), Wyzwania polskiej geologii: 3. Polski Kongres Geologiczny, Polskie Towarzystwo Geologiczne, Kraków, 341-342.

Sikora R., 2017. Landslides and its relation with faults and hidden fractures zones - results from the lidar-based dem and structural analysis (Silesian Beskid, Outer Carpathians). [in:] Alonso E. \& Pinyol N. (eds.), Proceedings of the First JTC1 Workshop on Advances in Landslide Understanding, 24-26 May 2017, Barcelona, International Center for Numerical Methods in Engineering (CIMNE), Barcelona, 126-129, [on-line:] http://congress.cimne.com/jtc1/frontal/doc/Ebook.pdf [access: 08.03.2018].

Sikora R. \& Piotrowski A., 2013a. Mapa osuwisk i terenów zagrożonych ruchami masowymi w skali 1: 10 000, gmina Wisła, powiat cieszyński, woj. śląskie. [on-line:] http://geoportal.pgi.gov.pl/portal/page/portal/SOPO [access: 08.03.2018].

Sikora R. \& Piotrowski A., 2013b. Objaśnienia do mapy osuwisk i terenów zagrożonych ruchami masowymi w skali 1: 10 000, gmina Wisła, powiat cieszyński, woj. śląskie. [on-line:] http://geoportal.pgi.gov.pl/portal/page/portal/ SOPO [access: 08.03.2018].

Sikora R. \& Piotrowski A., 2013c. Blokowiska w koluwiach wybranych osuwisk w obszarze źródłowym Wisły (Beskid Śląski). [in:] Krobicki M. \& Feldman-Olszewska A. (red.), Głębokomorska sedymentacja fliszowa: sedymentologiczne aspekty historii basenów karpackich: V Polska Konferencja Sedymentologiczna POKOS 5'2013: 16-19.05.2013, Żywiec: abstrakty referatów i posterów oraz artykuły: przewodnik do wycieczek, Państwowy Instytut Geologiczny - Państwowy Instytut Badawczy, Warszawa, 224-225.

Sikora R. \& Piotrowski A., 2013d. Zagadnienia osuwiskowe w rejonie Baraniej Góry (Beskid Śląski). [in:] Krobicki M. \& Sikora R. (red.), Wyzwania geologii regionu górnoślaskiego w XXI wieku: LXXXII Zjazd Naukowy Polskiego Towarzystwa Geologicznego, Ustroń, 19-21 września 2013 r.: przewodnik wycieczek terenowych, Państwowy
Instytut Geologiczny - Państwowy Instytut Badawczy, Warszawa, 98-105.

Słomka T., 1995. Głębokomorska sedymentacja silikoklastyczna warstw godulskich Karpat. Prace Geologiczne Polska Akademia Nauk. Oddział w Krakowie. Komisja Nauk Geologicznych, 139, Wyd. PAN, Kraków.

Starkel L., 1960. Rozwój rzeźby Karpat fliszowych w holocenie. Prace Geograficzne - Polska Akademia Nauk. Instytut Geografii, 22, Wydawnictwa Geologiczne, Warszawa.

Starkel L., 1972. Charakterystyka rzeźby polskich Karpat (i jej znaczenie dla gospodarki ludzkiej). Problemy Zagospodarowania Ziem Górskich, 10, 75-150.

Szura C., 2007. Jaskinia Miecharska cave (Beskid Śląski Mts., Polish Outer Carpathians): case study of the crevice -type cave developed on a sliding surface. Nature Conservation, 63, 57-68.

Szura C., 2010. Jaskinia Miecharska. Beskidzki gigant. Zacisk: Polskie Towarzystwo Turystyczno-Krajoznawcze. Oddział Bielsko-Biała, Klub Taternictwa Jaskiniowego "Speleoklub", 26, 14-18.

Thiel K. (red.), 1989. Kształtowanie fliszowych stoków karpackich przez ruchy masowe na przykładzie badań na stoku Bystrzyca w Szymbarku: praca zbiorowa. Prace Instytutu Budownictwa Wodnego PAN, 17, Instytut Budownictwa Wodnego Polskiej Akademii Nauk, Gdańsk - Kraków.

Tokarski A.K., 1975. Structural analysis of the Magura unit between Krościenko and Zabrzeż (Polish Flysch Carpathians). Annales Geologorum Societatis Poloniae, 45, 327-359.

Tomaszczyk M., 2005. Zależność między kierunkami korytarzy jaskiń pseudokrasowych a spękaniami ciosowymi w NE części Beskidu Śląskiego. Correlation between orientation of pseudokarst caves and joints in NE part of Silesian Beskid Mts. (Outer Carpathians). Przegląd Geologiczny, 53, 2, 168-174.

Unrug R., 1963. Istebna Beds - a fluxoturbidity formation in the Carpathian Flysch. Annales Societatis Geologorum. Poloniae, 33, 49-92.

Urban J., Margielewski W. \& Klassek G., 2010. Jaskinia Malinowska. [in:] Szelerewicz M. \& Urban J., Materiały 44. Sympozjum Speleologicznego, Wisła, 8-10.10.2010 r., Sekcja Speleologiczna Polskiego Towarzystwa Przyrodników im. M. Kopernika, Instytut Ochrony Przyrody PAN, Kraków, 26-27.

Wilkinson M.W., McCaffrey K.J, Jones R.R., Roberts G.P., Gregory L.C., Walters R.J., Wedmore L., Goodall H. \& Iezzi F., 2017. Near-field fault slip of the 2016 Vettore $M_{w}$ 6.6 earthquake (Central Italy) measured using low-cost GNSS. Scentific Reports, 7, article number 4612. DOI: 10.1038/s41598-017-04917-w.

Wojciechowski T., 2009. Geologiczna analiza osuwisk z wykorzystaniem satelitarnej interferometrii radarowej na przykładzie rejonu Nowego Sącza. Biblioteka Wydziału Nauk o Ziemi, Uniwersytet Śląski, Sosnowiec [Ph.D. thesis].

Wójcik A., 1997. Osuwiska w dorzeczu Koszarawy - strukturalne i geomorfologiczne ich uwarunkowania (Karpaty Zachodnie, Beskid Żywiecki). Biuletyn Państwowego Instytutu Geologicznego, 376, 5-42.

Wójcik A. \& Wojciechowski T., 2016. Osuwiska jako jeden z ważniejszych elementów zagrożeń geologicznych w Polsce. Przegląd Geologiczny, 64, 701-709. 
Wójcik A. \& Zimnal Z., 1996. Osuwiska wzdłuż doliny Sanu między Bachórzcem a Reczpolem (Karpaty, Pogórze Karpackie). Biuletyn Państwowego Instytutu Geologicznego, 374, 77-91.

Ziętara T., 1968. W sprawie klasyfikacji osuwisk w Karpatach fliszowych. Sprawozdania z Posiedzeń Komisji Naukowych - Polska Akademia Nauk. Oddział w Krakowie, 11, 354-357.

Zabuski L., Thiel K. \& Bober L., 1999. Osuwiska we fliszu Karpat polskich: Geologia, modelowanie, obliczenia stateczności. IBW PAN, Gdańsk.

Ziętara T., 1964. O odmładzaniu osuwisk w Beskidach Zachodnich. Przeglad Geograficzny, 22, 55-86.

Ziętara T., 1968. Rola gwałtownych ulew i powodzi w modelowaniu rzeźby Beskidów. Prace Geograficzne - Polska Akademia Nauk. Instytut Geografii, 60, Wydawnictwo Geologiczne, Warszawa.
Ziętara T., 1988. Landslides areas in the Polish Flysch Carpathians. Folia Geographica Physica, 20, 21-67.

Ziętara T. \& Bajgier M., 1989. Role of tectonics in development of landslides in the Beskid Śląski. [in:] Pinczés Z. (ed.), Carpatho-Balkan Geomorphological Commission: Proceedings, Debrecen, 191-197.

Zuchiewicz W., 1995. Selected aspects of neotectonics of the Polish Carpathians. Folia Quaternaria, 66, 145-204.

Zuchiewicz W., 1999. Przydatność metod morfometrycznych w ocenie tendencji neotektonicznych Karpat polskich. Przeglad Geologiczny, 47, 851-854.

Żytko K., ZającR., GucikS., Ryłko W., Oszczypko N., Garlicka I., Nemčok J., Elias M., Mencik E. \& Stranik Z., 1988. Map of tectonic elements of the Western Outer Carpathians and their Foreland. [in:] Poprawa D. \& Nemčok J. (eds.), Geological Atlas of the Western Carpathians and their Foreland, Państwowy Instytut Geologiczny, Warszawa (Table 3). 